\title{
Therapeutic Efficacy of onabotulinumtoxinA Delivered Using Various Approaches in Sensory Bladder Disorder
}

\author{
Po-Yen Chen ${ }^{1} \mathbb{D}$, Wei-Chia Lee ${ }^{1, *} \mathbb{C}$, Hung-Jen Wang ${ }^{1,2}$ and Yao-Chi Chuang ${ }^{1,2}$ \\ 1 Division of Urology, Kaohsiung Chang Gung Memorial Hospital and Chang Gung University College of \\ Medicine, Kaohsiung 83301, Taiwan; patrick7613@gmail.com (P.Y.C.); hujewang@yahoo.com.tw (H.-J.W.); \\ chuang82@ms26.hinet.net (Y.-C.C.) \\ 2 Center for Shock Wave Medicine and Tissue Engineering, Kaohsiung Chang Gung Memorial Hospital, \\ Kaohsiung 83301, Taiwan \\ * Correspondence: dinor666@ms32.hinet.net; Tel.: +886 7-7317123; Fax: 886-7-7318762
}

Received: 20 December 2019; Accepted: 21 January 2020; Published: 23 January 2020

\begin{abstract}
Cystoscopic onabotulinumtoxinA (onaBoNTA) intradetrusor injection is an efficient and durable modality for treating sensory bladder disorders. However, the inconvenience of using the cystoscopic technique and anesthesia, and the adverse effects of direct needle injection (e.g., haematuria, pain, and infections) have motivated researchers and clinicians to develop diverse injection-free procedures to improve accessibility and prevent adverse effects. However, determining suitable approaches to transfer onaBoNTA, a large molecular and hydrophilic protein, through the impermeable urothelium to reach therapeutic efficacy remains an unmet medical need. Researchers have provided potential solutions in three categories: To disrupt the barrier of the urothelium (e.g., protamine sulfate), to increase the permeability of the urothelium (e.g., electromotive drug delivery and low-energy shock wave), and to create a carrier for transportation (e.g., liposomes, thermosensitive hydrogel, and hyaluronan-phosphatidylethanolamine). Thus far, most of these novel administration techniques have not been well established in their long-term efficacy; therefore, additional clinical trials are warranted to validate the therapeutic efficacy and durability of these techniques. Finally, researchers may make progress with new combinations or biomaterials to change clinical practices in the future.
\end{abstract}

Keywords: drug delivery; interstitial cystitis; onabotulinumtoxinA; overactive bladder; painful bladder syndrome

Key Contribution: This review examines the studies of injection-free onaBoNTA delivery for the treatment of sensory bladder disorders.

\section{Introduction}

Since the first injection of onabotulinumtoxinA (onaBoNTA) for a patient with detrusor sphincter dyssynergia in 1988, onaBoNTA has been extensively used in the treatment of lower urinary tract dysfunction [1]. At present, the intradetrusor injection of onaBoNTA is indicated for treating neurogenic and idiopathic overactive bladder $(\mathrm{OAB})$ [2]. Although the intradetrusor injection of onaBoNTA is highly efficacious in the treatment of $\mathrm{OAB}$ and other sensory bladder disorders, some perioperative complications (e.g., pain, haematuria, increased post-void residual volume, acute urinary retention, and urinary tract infections) and inconvenience related to performing the cystoscopic procedure along with anesthesia, remain a concern [3]. Hence, researchers have attempted to deliver onaBoNTA by using different approaches to improve accessibility and decrease adverse effects in patients. This review 
examines these experimental studies of injection-free onaBoNTA delivery for the treatment of sensory bladder disorders.

\section{Sensory Bladder Disorders}

Sensory bladder disorders are caused by sensation abnormality and include OAB syndrome and interstitial cystitis/painful bladder syndrome (IC/PBS). Both of these have similar irritative bladder symptoms but have different clinical features in terms of urinary incontinence and bladder pain. In $\mathrm{OAB}$ patients, urgency is the cardinal symptom along with urinary frequency, nocturia, and urgent incontinence. By contrast, the patients with (IC/PBS) are bothered by bladder pain, urinary frequency, and nocturia [4]. The brief description of probable sensory disturbances occurrence are illustrated in Figure 1.

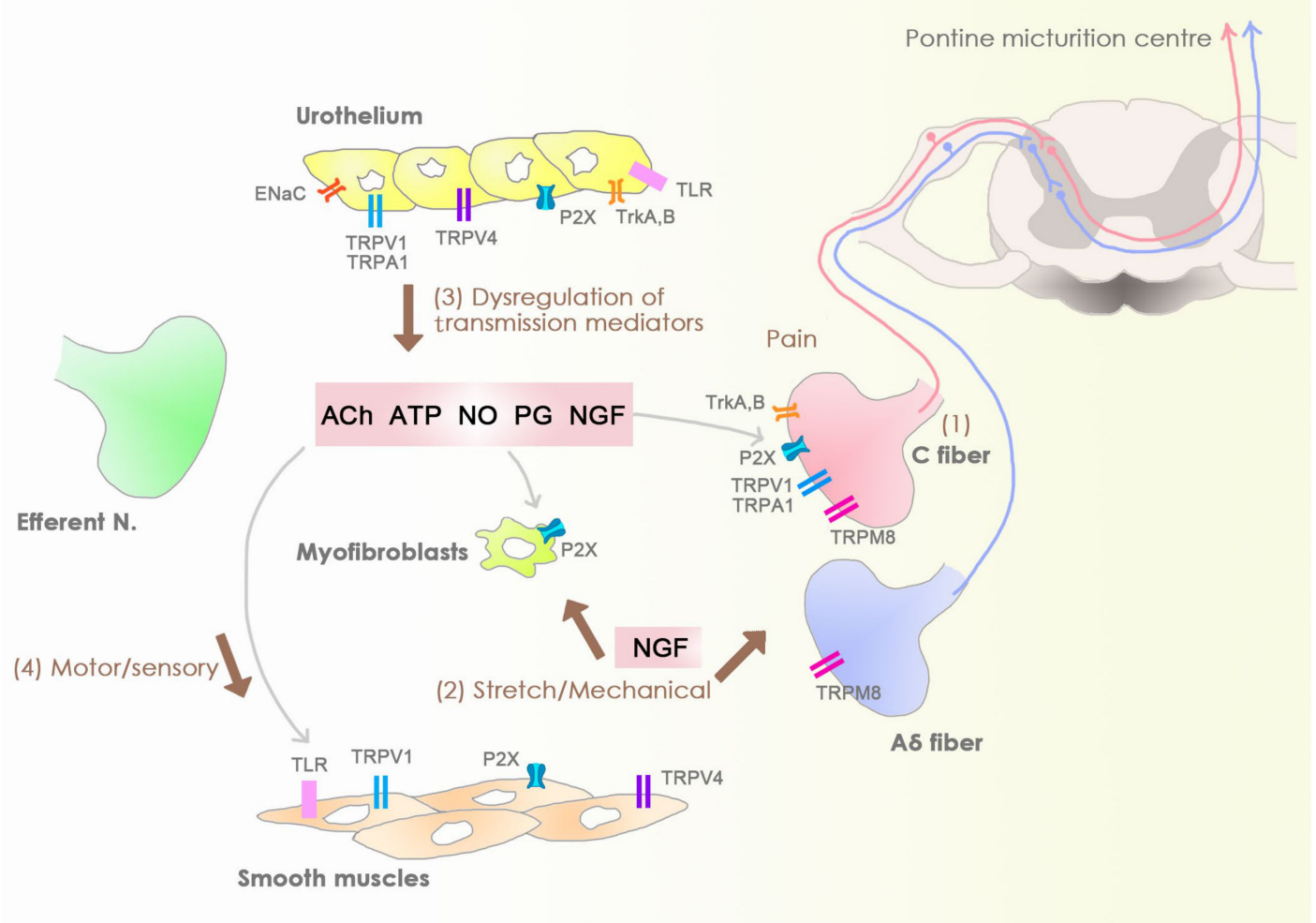

Figure 1. Sensory bladder disorders: The sensory disturbances of an unstable bladder may elicit from activation of silence C-fibers due to noxious stimuli (1), stretching stretch-mediated receptors, and myofibroblasts (2), chemicals inducing urothelial signaling (3), and signals generated in a modulated motor-sensory system (4).

The pathophysiology of $\mathrm{OAB}$ is not well understood but may involve disorders of urothelial signaling, detrusor muscle instability, and nerve hyperexcitability [5]. For instance, metabolic derangement, bladder outlet obstruction, and inflammation can underlie the disturbances of these three factors of the bladder and can contribute to OAB. OAB has a high prevalence (around 16\%-20\%) [6], and its symptoms have detrimental effects on individual quality of life and incur societal costs for public health [7]. IC/PBS may develop due to urothelial dysfunction and cause an inflammatory reaction of the bladder and cause permanent inflammatory imprinting in the central nervous system [4]. Dysfunction of the urothelial lining may cause the activation of mast cells and the winding up of capsaicin-sensitive nerves. The release of neurotransmitters from the urothelium and nerve endings then provokes peripheral and central pain sensitization. The prevalence of IC/PBS among adult women is estimated to be between $2.7 \%$ and $6.5 \%$ [8]. 
The first-line therapies for $\mathrm{OAB}$ patients are behavioral therapies and lifestyle modifications. The second-line treatments include the monotherapy or combinations of antimuscarinics and the $\beta 3$-adrenoceptor agonist. For refractory cases of $\mathrm{OAB}$, intradetrusor injection of onaBoNTA or neuromodulation can be considered as third-line therapies [9].

For patients with IC/PBS, patient education and behavioral modification are essential in first-line therapy. The oral medications of amitriptyline, cimetidine, hydroxyzine, or pentosan polysulphate as well as the intravesical treatments of dimethyl sulphoxide (DMSO), heparin, or lidocaine are considered as second-line therapies. The third-line treatments include cystoscopic low-pressure hydrodistention under anesthesia and fulguration for Hunner's lesions. Intradetrusor injection of onaBoNTA is the fourth-line therapy for selective IC/PBS patients [10].

\section{Mechanism of Action of onaBoNTA}

OnaBoNTA, a botulinumtoxinA with the most well-understood effects of therapy, is used in clinical settings. It is a neurotoxic protein that can bind its $100 \mathrm{kDa}$ heavy chain to synaptic vesicle protein 2 as its protein receptor and enter the neuron endings; thereafter, its $50 \mathrm{kDa}$ light chain is released, translocated to the cytosol [2,3]. The light chain of onaBoNTA cleaves synaptosomal nerve-associated protein (SNAP) 25, blocks soluble N-ethylmaleimide-sensitive fusion attachment protein receptor complex, and interferes with synaptic acetylcholine vesicle fusion to the cell membrane from presynaptic efferent nerves; thus, it causes paralysis of the detrusor muscle and modulation of the postsynaptic receptors. Furthermore, onaBoNTA intradetrusor injection possesses the ability to interrupt C-fibre sensory transmission, block the release of neurotransmitters (e.g., substance P, adenosine triphosphate, and calcitonin gene-related peptide), prevent receptor trafficking (TRPV1 as an example), and decrease ATP and nerve growth factor (NGF) releasing and affects preganglionic parasympathetic nerve terminals [11]. Due to its chemodenervation effects, onaBoNTA may provide anti-inflammation and antinociceptive effects for patients against neurogenic inflammation along with blocking the release of neuropeptides [3].

\section{Barriers and Sensory Web of the Bladder Mucosa and Submucosa}

The bladder wall has four layers: Mucosa, submucosa (lamina propria and muscularis mucosae), detrusor muscle, and serous layer (tunica serosa) [12]. The transitional urothelium extends from the renal pelvis to the ureter and inner bladder wall. The urothelial apical surface lines a sulfated polysaccharide glycosaminoglycan layer, which acts as a non-specific anti-adherence factor and as a defense mechanism against infection. The urothelium is composed of three layers: A basal cell layer, an intermediate layer, and a superficial layer containing polarized umbrella cells (diameters of 25-250 $\mu \mathrm{m}$ ). The uroplakin membrane and tight junction complexes of the umbrella cell layer play important roles in the barrier function of the urothelium. The apical uroplakin membrane may reduce the permeability of the cells to small molecules (e.g., water, urea, and protons). The tight junction complexes can reduce the movement of ions and solutes between cells and specialized lipid molecules. The intermediate spindle cells, found beneath the umbrella layer, have up to five strata, and they can rapidly differentiate into umbrella cells when the barrier is disrupted. The single-layer mononuclear basal cells adhere to the intermediate cells and to the basement membrane. The suburothelial layer consists of interstitial cells, myofibroblasts, blood vessels, and afferent sensory nerve endings at the lamina propria beneath the basal membrane.

In addition to the barrier function, the mucosa layer serves as a sensory web, which comprises the urothelium and sensory afferent and efferent nerves linked by gap junctions, which amplify and transmit the signals among the mucosa, nervous, and muscular systems $[3,12]$. The unmyelinated C-fiber endings are widespread in the urothelium and lamina propria. Parasympathetic nerve cells and intramural ganglion cells are also embedded among the lamina propria. The schematic diagram of the bladder mucosa and submucosa are illustrated in Figure 2. 


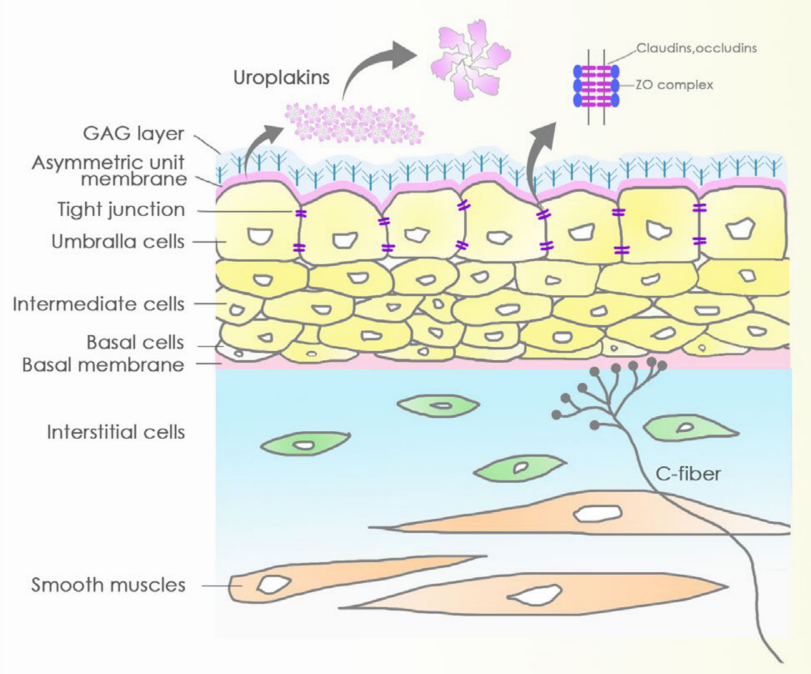

Figure 2. Schematic diagram of barriers and sensory web of the bladder mucosa. Impermissible bladder barrier consists of the glycosaminoglycan (GAG) layer, uroplakins, and tight junction. The sensory web was innervated by neuron-like urothelium.

\section{Intravesical Delivery of onaBoNTA}

\subsection{Passive Diffusion}

In an animal study, Khera et al. reported that onaBoNTA failed to reach the muscle layer by direct bladder instillation. Another report from Coelho et al. further supported the lack of effect of onaBoNTA when simply instilled in the bladder with an intact urothelium $[13,14]$. Bladder instillation of onaBoNTA was less efficient owing to multiple factors. First, onaBoNTA is a large molecule (150 KDa). For targeting the suburothelium and detrusor muscle, passive diffusion is limited by tight junctions [15]. Second, the onaBoNTA agents might be diluted and degraded by urine proteases due to daily urine production of 800 to $2000 \mathrm{~mL}$. Therefore, urologists need a modality that can cross the urothelium barrier, penetrate deep into the bladder, and persist for a sufficient time. Some studies have attempted to overcome the problems with different approaches, as illustrated in Figure 3.

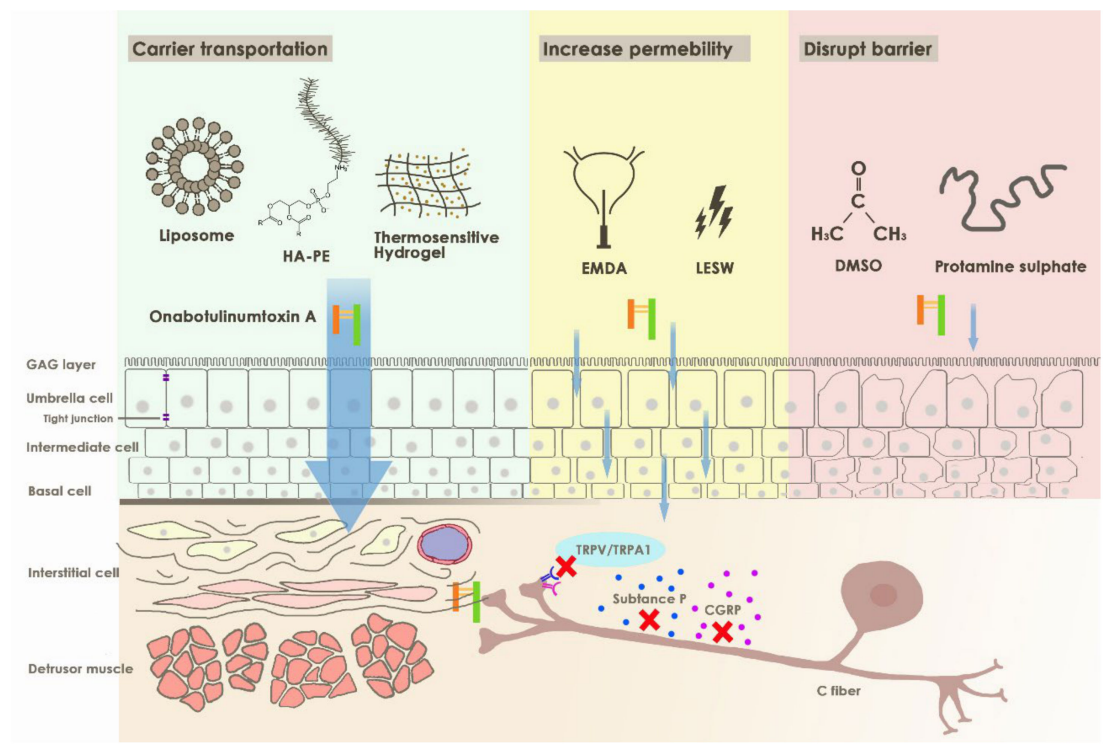

Figure 3. Illustration of different approaches for onabotulinumtoxinA delivery in sensory bladder disorder. 


\subsection{Disrupt Barrier}

\subsubsection{Protamine Sulfate}

Protamine sulfate, an arginine-rich protein, can increase permeability in the apical membrane to both cations and anions by altering the membrane conductance in different concentrations and by damage to the surface of the bladder mucosa [16,17]. In addition, protamine sulfate also has analgesic effects, tissue-protective effects, and pro-inflammatory response suppression for relieving bladder pain in mice [18].

In a study, rats with spinal cord injuries received $1 \mathrm{~mL}$ of $1 \%$ protamine sulfate bladder instillation, followed by $1 \mathrm{~mL}$ of onaBoNTA (20 U). By using this procedure, Khera et al. reported that onaBoNTA could inhibit vesical sensory mechanisms but could not alter bladder motor function in rats. These results denoted that onaBoNTA could not penetrate across the urothelium into detrusor muscle, even after the urothelium was disrupted by protamine sulfate instillation [13].

\subsubsection{Dimethyl Sulphoxide}

Dimethyl sulphoxide (DMSO) intravesical instillation was developed some decades ago by Stewart et al. [19]. Now, DMSO is an FDA-approved second-line therapy for IC/BPS [20]. DMSO, an organic solvent, can desquamate urothelium, disrupt mucosa, and interfere with cellular phospholipid membranes. In addition, DMSO luminal effluent leads to a loss of urothelial layers and mucosal folding; thus, it facilitates membrane penetration to increase urothelium permeability and to cause leakage of cytosolic contents. Besides, DMSO was found to inhibit the stretch-activated adenosine triphosphate release from urothelial cells and relax the detrusor muscle in rabbits [21].

Petrou et al. conducted a phase $1 / 2$ study in treating refractory idiopathic detrusor overactivity in women by using $300 \mathrm{U}$ of onaBoNTA plus 50\% DMSO solution for instillation [22]. The results demonstrated that patients who underwent this treatment had improved incontinence events, decreased Indevus Urgency Severity Scale scores, and improved quality of life as recorded by questionnaires (i.e., 6-item Urogenital Distress Inventory, bothersome score, and Incontinence Impact Questionnaire short-form) at the endpoint of the 3-month observation.

\subsection{Increase Permebility}

\subsubsection{Electromotive Drug Administration}

Electromotive drug administration (EMDA) was designed in 1996 to transfer drugs into the bladder submucosa area for treating bladder cancer [23]. The previous review mentioned that EMDA contained three phenomena: Iontophoresis, electro-osmosis, and electroporation. Iontophoresis passes an electrical current forming the active charged ingredient and propels a substance into tissues. Electro-osmosis transfers non-ionized polar molecules and ionized molecules against their coulombic gradients. And electroporation increases electrical conductivity and permeability of the cell plasma membranes [24]. In clinical trials, electromotive delivery of mitomycin has been used to treat non-muscle-invasive bladder cancer to reduce its recurrence rate [25,26]. A basic study also reported that EMDA systems could enhance mitomycin transport into the full-thickness of the bladder wall without chemical modification or without changing the histology of the urothelium, lamina propria, and muscularis [27]. Nowadays, some studies apply EMDA on improving local anesthesia effects and the treatment of detrusor overactivity and interstitial cystitis in patients. The drugs under EMDA delivery studies include lidocaine, mitomycin C, oxybutynin, verapamil, resiniferatoxin, and dexamethasone [28].

Researchers applied EMDA to transfer onaBoNTA into the bladder of children with myelomeningocele-associated neurogenic bladder. They instilled onaBoNTA solution into children's bladders and delivered $10 \mathrm{~mA}$ of pulsed currents for 15 or $20 \mathrm{~min}$ without anesthesia [29,30]. The results of these studies demonstrated that children with myelomeningocele-associated neurogenic bladder 
might benefit from this administration in terms of urinary incontinence and vesicoureteral reflux. Because these studies lacked a control group, the treatment benefit in other sensory disorders remains unclear.

\subsubsection{Low-Energy Shock Wave}

The term "shock wave" indicates a high-energy sound wave that terminates in a burst of energy, similar to a mini-explosion. Shock waves, continuously transmitted sonic waves at a $16-20 \mathrm{MHz}$ frequency, can carry energy from an area of positive pressure to an area of negative pressure to propagate through mediums. Shock waves (SWs) may be applied in various medical situations because of its unique physical, physical-chemical, chemical, and biological effects. Thus, LESWs per se might have therapeutic effects for inflammatory disorders, such as chronic prostatitis and cystitis. In the physical phase, the tensile force of SW creates negative pressure, which causes cavitation and molecule ionization to affect the permeability of the plasma membrane. In basic studies, high energy levels $\left(>0.12 \mathrm{~mJ} / \mathrm{mm}^{2}\right)$ SWs altered cell structure and organelles. By contrast, the capability of low-energy shock waves was to increase the tissue permeability without consequent cytotoxicity temporarily; thus, LESWs can facilitate the transfer of pharmaceutical molecules into cells [31].

Through LESW induction, Chuang et al. recorded bladder urothelium leakage of Gd-diethylenetriamine pentaacetic contrast medium through magnetic resonance imaging in rats [32]. Under these circumstances, intravesical onaBoNTA can penetrate into the bladder and suppress the rat's bladder hyperactivity induced by acetic acid. Nageib et al. conducted a clinical study to prove this concept of injection-free onaBoNTA delivery through LESWs [33]. They recruited 15 refractory OAB patients who received $100 \mathrm{U}$ of onaBoNTA bladder instillation along with LESWs consisting of 3000 shocks over $10 \mathrm{~min}$. The study results revealed a significant decrease in OAB symptom scores in patients at the 1and 2-month checkpoints, but not at 3 months.

\subsection{Carrier Transportation}

\subsubsection{Liposome Formulation of onaBoNTA}

Liposomes are spherical lipid vesicles composed of phospholipid bilayers surrounded by an aqueous core. Liposomes can incorporate pharmaceutical drugs, both hydrophilic and hydrophobic, and transfer various sizes of drug molecules through the urothelium via the endocytosis mechanism [34]. Moreover, liposomes can coat the urothelium and assist in its repair in case of injury. Thus, only empty liposome bladder instillation can ameliorate the urinary symptoms and pain scale of patients with IC/PBS [35].

Chuang et al. examined the effects of liposome formulation of onaBoNTA (hereafter, lipotoxin) in a rat model [36]. The results demonstrated that intravesical lipotoxin instillation could cleave SNAP-25, inhibit calcitonin gene-related peptide release from afferents, and suppress bladder hyperactivity induced by acetic acid. Furthermore, Kuo et al. reported that bladder instillation of lipotoxin could reduce the urinary frequency at 1 month in $\mathrm{OAB}$ patients [37]. In a subsequent clinical trial, Chuang et al. recruited 62 participants with $\mathrm{OAB}$ and demonstrated that a single intravesical instillation of lipotoxin did work at 4 weeks by improving urgency but not beyond that time point [38].

Researchers are also considering the application of lipotoxin for IC/BPS or other bladder sensory disorders. However, Chuang and Kuo demonstrated that the therapeutic effect of a single intravesical instillation of lipotoxin for patients with IC/PBS would be similar to the placebo effect [39]. Recently, Lee et al. investigated the effects of lipotoxin on ketamine-induced ulcerative cystitis in rats [40]. The results showed repeated lipotoxin bladder instillation could protect the urothelium against the insults of urinary ketamine and its metabolites and restore the urothelial tight junction and adhesion proteins (i.e., zonula occludens-1 and E-cadherin). The chemodenervation effect of onaBoNTA could also be observed in this experiment, including the modulation of the detrusor M2 receptor, suppression of the neurogenic inflammation processes, and reduction in immune reactions. Hence, further studies 
validating the long-term effects of lipotoxin in single or multiple instillations in treating sensory bladder disorders are warranted.

\subsubsection{Intravesical Thermosensitive Hydrogel}

Thermosensitive hydrogel consists of PEG-PLGA-PEG triblock copolymers, which can provide a composition to slowly release low-molecular-weight hydrophobic drugs lasting for 2 months [41]. The thermosensitive hydrogel exists in a liquid state at room temperature $\left(25^{\circ} \mathrm{C}\right)$ or below, but converts to a semisolid state at elevated temperatures, such as body temperature $\left(37^{\circ} \mathrm{C}\right)$ [42]. After the hydrogel is instilled into the bladder, it can act as a matrix filled drug for maintaining a prolonged exposure of drugs at the urothelium.

For treating patients with idiopathic $\mathrm{OAB}, \mathrm{Krhut}$ et al. conducted a 1-month clinical trial using onaBoNTA embedded in an inert hydrogel [43]. The results revealed that intravesical instillation of 200U onaBoNTA, embedded in TC-3 gel, might have a therapeutic benefit for some patients with OAB. In a pilot study, Rappaport et al. used onaBoNTA embedded in TC-3 gel to treat patients with IC/PBS and reported a borderline therapeutic effect for participants on the visual analog scale at week 12 [44].

\subsubsection{Hyaluronan-Phosphatidylethanolamine}

Hyaluronic acid, also called hyaluronan (HA), is a hydrophilic polysaccharide and a common ingredient in skincare products for its epidermis-healing function. A nonparticulate formula was developed by linking HA to phosphatidylethanolamine (PE), which increases HA levels through epidermal cell layers. This high viscosity formulation of HA-PE could be applied as a carrier for transferring large proteins, such as onaBoNTA, through the urothelium. In a rat model, Shatoury et al. proved that bladder instillation of onaBoNTA enmeshed in HA-PE could transfer onaBoNTA through bladder mucosa. According to the study, both routes of HA-PE and intradetrusor injections had comparable SNAP-25 cleavage [45].

\section{Conclusions}

In this review, the suitable modalities for transferring onaBoNTA into the bladder were discussed. The summary of therapeutic effects in clinical trials among various drug delivery systems is illustrated in Table 1. The efficacy of current solutions did not reach a similar efficacy as intradetrusor injections. In sum, passive diffusion is less effective and practical in clinical use. Protamine sulfate failed to deliver the onaBoNTA into the detrusor layer of the bladder, even in an animal model. Using EMDA to conduct onaBoNTA into the bladder seems promising in treating neurogenic OAB in children. It resulted in a 9-month decrease of detrusor pressure and alleviated urinary incontinence episodes and vesicoureteral reflux. LESWs can help the onaBoNTA penetrate into the bladder and maintain its therapeutic effects for 2 months in a clinical trial. Using DMSO as a delivery agent of onaBoNTA may benefit patients with idiopathic detrusor overactivity by improving urinary symptoms and quality of life for 1-3 months. The concept of liposome-encapsulated onaBoNTA has been proven in rat models. However, in clinical trials, the current lipotoxin regimen can only improve the OAB symptoms of patients for 1 month. At present, a thermosensitive hydrogel is also under clinical trial for treating urothelial cancer by embedding mitomycin. In terms of treating OAB or IC/PBS, the therapeutic effect of thermosensitive hydrogel embedded with onaBoNTA is barely satisfactory. HA-PE, a novel agent, can carry onaBoNTA across the urothelium of rats' bladders. Additional clinical trials are needed to prove its efficacy. It is worth noting that most of the literatures in this review did not report serious adverse effects during the studies. It may attribute to the small sample size and single arm studies thus that determining causes and unexpected adverse events might be unnoticed. The needle-free delivery techniques of onaBoNTA through bladder instillation should continuously be improved for treating sensory bladder disorders, and the safety and efficacy are worthy of being further investigated. 
Table 1. Clincal trials for sensory bladder disorders with onabotulinumtoxinA injection-free procedures.

\begin{tabular}{|c|c|c|c|c|c|c|}
\hline $\begin{array}{l}\text { Research and } \\
\text { Modalities }\end{array}$ & No.Pts & $\begin{array}{l}\text { Study } \\
\text { Design }\end{array}$ & $\begin{array}{l}\text { Follow-up } \\
\text { Duration }\end{array}$ & $\begin{array}{l}\text { Patients } \\
\text { Criteria }\end{array}$ & $\begin{array}{c}\text { Modalities } \\
\text { Utilization and } \\
\text { onaBoNTA Dose }\end{array}$ & $\begin{array}{c}\text { Outcome at the End } \\
\text { Point }\end{array}$ \\
\hline $\begin{array}{l}\text { Petrou et al. [22] } \\
\text { (DMSO) }\end{array}$ & 25 & $\begin{array}{l}\text { Single arm } \\
\text { Prospective } \\
\text { cohort }\end{array}$ & 3 months & $\begin{array}{c}\text { Adult } \\
\text { females } \\
\text { idiopathic } \\
\text { DO }\end{array}$ & $\begin{array}{c}\text { DMSO }(50 \% 50 \mathrm{~mL}) \\
\text { plus 300U } \\
\text { onaBoNTA }\end{array}$ & $\begin{array}{c}\text { Improve incontinence at } 1 \\
\text { month, but not at } 3 \\
\text { months }\end{array}$ \\
\hline $\begin{array}{c}\text { Kajbafzadeh et al. } \\
\text { [29] } \\
\text { (EMDA) }\end{array}$ & 15 & $\begin{array}{l}\text { Single arm } \\
\text { Prospective } \\
\text { cohort }\end{array}$ & 9 months & $\begin{array}{c}\text { Children } \\
\text { MMC-related } \\
\text { DO }\end{array}$ & $\begin{array}{c}\text { onaBoNTA (10 } \\
\mathrm{U} / \mathrm{kg} \text { ) plus EDMA } \\
\text { delivered } 10 \mathrm{~mA} \text { for } \\
15 \mathrm{~min}\end{array}$ & $\begin{array}{l}\text { Improve incontinence in } \\
80 \% \text { cases and decrease } \\
\text { VUR grade in } 58 \% \text { cases }\end{array}$ \\
\hline $\begin{array}{c}\text { Kajbafzadeh et al. } \\
\text { [30] } \\
\text { (EMDA) }\end{array}$ & 24 & $\begin{array}{l}\text { Single arm } \\
\text { Prospective } \\
\text { cohort }\end{array}$ & 6 years & $\begin{array}{l}\text { Children } \\
\text { MMC-related } \\
\text { DO }\end{array}$ & $\begin{array}{c}\text { onaBoNTA (10 } \\
\mathrm{U} / \mathrm{kg} \text { ) plus EDMA } \\
\text { delivered } 10 \mathrm{~mA} \text { for } \\
20 \mathrm{~min}\end{array}$ & $\begin{array}{l}\text { Followed up at } 1,2,3,5,6 \\
\text { years, and } 75 \%, 45.5 \% \text {, } \\
37.5 \%, 33 \%, 29.1 \% \text { of } \\
\text { patients remain } \\
\text { completely dry }\end{array}$ \\
\hline $\begin{array}{l}\text { Nageib et al. [33] } \\
\text { (LESW) }\end{array}$ & 15 & $\begin{array}{l}\text { Single arm } \\
\text { Prospective } \\
\text { cohort }\end{array}$ & 3 months & $\begin{array}{l}\text { Adults } \\
\text { idiopathic } \\
\text { DO }\end{array}$ & $\begin{array}{l}\text { 100U onaBoNTA } \\
\text { plus LESW } 3000 \\
\text { shocks }(6.6 \\
\text { mJ/shock, } 300 \\
\text { shocks/min) }\end{array}$ & $\begin{array}{c}\text { Improve OABSS at } 1,2 \\
\text { months, but not at } 3 \\
\text { months. }\end{array}$ \\
\hline $\begin{array}{l}\text { Kuo et al. [37] } \\
\text { (Liposome) }\end{array}$ & 24 & $\begin{array}{l}\text { Double-blind } \\
\text { RCT }\end{array}$ & 3 months & $\begin{array}{l}\text { Adults } \\
\text { OAB }\end{array}$ & $\begin{array}{l}\text { 200U onaBoNTA } \\
\text { plus } 80 \mathrm{mg} \\
\text { liposomes }\end{array}$ & $\begin{array}{c}\text { Improve frequency at } 1 \\
\text { month, but not at } 3 \\
\text { months }\end{array}$ \\
\hline $\begin{array}{l}\text { Chuang et al. [38] } \\
\text { (Liposome) }\end{array}$ & 62 & $\begin{array}{l}\text { Multicenter } \\
\text { double-blind } \\
\text { RCT }\end{array}$ & 4 weeks & $\begin{array}{l}\text { Adults } \\
\text { OAB }\end{array}$ & $\begin{array}{l}200 \mathrm{U} \text { onaBoNTA } \\
\text { plus } 80 \mathrm{mg} \\
\text { liposomes }\end{array}$ & $\begin{array}{l}\text { Decrease micturition } \\
\text { events and urgency } \\
\text { severity at } 4 \text { weeks }\end{array}$ \\
\hline $\begin{array}{c}\text { Chuang and Kuo } \\
\text { [39] } \\
\text { (Liposome) }\end{array}$ & 96 & $\begin{array}{c}\text { Multicenter } \\
\text { double-blind } \\
\text { RCT }\end{array}$ & 4 weeks & $\begin{array}{l}\text { Adults } \\
\text { IC/BPS }\end{array}$ & $\begin{array}{l}200 \mathrm{U} \text { onaBoNTA } \\
\text { plus } 80 \mathrm{mg} \\
\text { liposomes }\end{array}$ & $\begin{array}{c}\text { Improve OSS, ICSI, ICPI, } \\
\text { VAS scores, but not } \\
\text { superior to placebo at } 4 \\
\text { weeks }\end{array}$ \\
\hline $\begin{array}{l}\text { Krhut et al. [43] } \\
\text { (Hydrogel) }\end{array}$ & 39 & $\begin{array}{l}\text { Double-blind } \\
\text { RCT }\end{array}$ & 1 month & $\begin{array}{l}\text { Adult } \\
\text { females } \\
\text { OAB }\end{array}$ & $\begin{array}{l}\text { 200U onaBoNTA } \\
\text { plus TC-3 gel }\end{array}$ & $\begin{array}{l}\text { Improve urgency, leakage } \\
\text { episodes, PPBC, OAB-q } \\
\text { scores at } 1 \text { month }\end{array}$ \\
\hline $\begin{array}{l}\text { Rappaport et al. [44] } \\
\text { (Hydrogel) }\end{array}$ & 15 & $\begin{array}{l}\text { Single arm } \\
\text { Prospective } \\
\text { cohort }\end{array}$ & 12 weeks & IC/BPS & $\begin{array}{c}\text { 200IU onaBoNTA } \\
\text { plus } 40 \mathrm{~mL} \text { TC-3 Gel }\end{array}$ & $\begin{array}{c}\text { Improve ICSI, VAS scores } \\
\text { at week } 12\end{array}$ \\
\hline
\end{tabular}

MMC, myelomeningocele; DO, detrusor overactivity; OSS, O'Leary-Sant symptom scores; IC/BPS, interstitial cystitis/bladder pain syndrome; ICSI, ICPI, Interstitial cystitis symptom, and problem indices; VAS, visual analog scale; PPBC, Patient Perception of Bladder Condition; OAB-q, Overactive Bladder Questionnaire; FBC, functional bladder capacity; GRA, global response assessment.

Author Contributions: P.-Y.C. and W.-C.L. wrote the manuscript and figures, H.-J.W. collected information and references; Y.-C.C. supervised and revised the paper. All authors have read and agreed to the published version of the manuscript.

Funding: This work is supported by Grants MOST104-2314-B-182A-081 from the Ministry of Science and Technology of the Republic of China and CMRPG8F0051-53 and CMRPG8J0271 from Chang Gung Medical Foundation.

Conflicts of Interest: The authors declare no conflict of interest.

\section{References}

1. Dykstra, D.D.; Sidi, A.A.; Scott, A.B.; Pagel, J.M.; Goldish, G.D. Effects of botulinum A toxin on detrusor-sphincter dyssynergia in spinal cord injury patients. J. Urol. 1988, 139, 919-922. [CrossRef]

2. Jhang, J.F.; Kuo, H.C. Botulinum Toxin A and Lower Urinary Tract Dysfunction: Pathophysiology and Mechanisms of Action. Toxins 2016, 8, 120. [CrossRef] [PubMed]

3. Jiang, Y.H.; Liao, C.H.; Kuo, H.C. Current and potential urological applications of botulinum toxin A. Nat. Rev. Urol. 2015, 12, 519-533. [CrossRef] [PubMed]

4. Grundy, L.; Caldwell, A.; Brierley, S.M. Mechanisms Underlying Overactive Bladder and Interstitial Cystitis/Painful Bladder Syndrome. Front. Neurosci. 2018, 12, 931. [CrossRef] 
5. Steers, W.D. Pathophysiology of overactive bladder and urge urinary incontinence. Rev. Urol. 2002, 4 (Suppl. S4), S7-S18.

6. Chuang, Y.C.; Liu, S.P.; Lee, K.S.; Liao, L.; Wang, J.; Yoo, T.K.; Chu, R.; Sumarsono, B. Prevalence of overactive bladder in China, Taiwan and South Korea: Results from a cross-sectional, population-based study. Low. Urin. Tract Symptoms 2019, 11, 48-55. [CrossRef]

7. Reynolds, W.S.; Fowke, J.; Dmochowski, R. The Burden of Overactive Bladder on US Public Health. Curr. Bladder Dysfunct. Rep. 2016, 11, 8-13. [CrossRef]

8. Berry, S.H.; Elliott, M.N.; Suttorp, M.; Bogart, L.M.; Stoto, M.A.; Eggers, P.; Nyberg, L.; Clemens, J.Q. Prevalence of symptoms of bladder pain syndrome/interstitial cystitis among adult females in the United States. J. Urol. 2011, 186, 540-544. [CrossRef]

9. Lightner, D.J.; Gomelsky, A.; Souter, L.; Vasavada, S.P. Diagnosis and Treatment of Overactive Bladder (Non-Neurogenic) in Adults: AUA/SUFU Guideline Amendment 2019. J. Urol. 2019, 202, 558-563. [CrossRef]

10. Hanno, P.M.; Erickson, D.; Moldwin, R.; Faraday, M.M. Diagnosis and treatment of interstitial cystitis/bladder pain syndrome: AUA guideline amendment. J. Urol. 2015, 193, 1545-1553. [CrossRef]

11. Coelho, A.; Cruz, F.; Cruz, C.D.; Avelino, A. Effect of onabotulinumtoxinA on intramural parasympathetic ganglia: An experimental study in the guinea pig bladder. J. Urol. 2012, 187, 1121-1126. [CrossRef] [PubMed]

12. Birder, L.; Andersson, K.E. Urothelial signaling. Physiol. Rev. 2013, 93, 653-680. [CrossRef] [PubMed]

13. Khera, M.; Somogyi, G.T.; Salas, N.A.; Kiss, S.; Boone, T.B.; Smith, C.P. In vivo effects of botulinum toxin A on visceral sensory function in chronic spinal cord-injured rats. Urology 2005, 66, 208-212. [CrossRef] [PubMed]

14. Coelho, A.; Cruz, F.; Cruz, C.D.; Avelino, A. Spread of onabotulinumtoxinA after bladder injection. Experimental study using the distribution of cleaved SNAP-25 as the marker of the toxin action. Eur. Urol. 2012, 61, 1178-1184. [CrossRef]

15. Haynes, M.D.; Martin, T.A.; Jenkins, S.A.; Kynaston, H.G.; Matthews, P.N.; Jiang, W.G. Tight junctions and bladder cancer (review). Int. J. Mol. Med. 2005, 16, 3-9. [CrossRef]

16. Tzan, C.J.; Berg, J.; Lewis, S.A. Effect of protamine sulfate on the permeability properties of the mammalian urinary bladder. J. Membr. Biol. 1993, 133, 227-242. [CrossRef]

17. Stein, P.C.; Pham, H.; Ito, T.; Parsons, C.L. Bladder injury model induced in rats by exposure to protamine sulfate followed by bacterial endotoxin. J. Urol. 1996, 155, 1133-1138. [CrossRef]

18. Stemler, K.M.; Crock, L.W.; Lai, H.H.; Mills, J.C.; Gereau, R.W.t.; Mysorekar, I.U. Protamine sulfate induced bladder injury protects from distention induced bladder pain. J. Urol. 2013, 189, 343-351. [CrossRef]

19. Stewart, B.H.; Branson, A.C.; Hewitt, C.B.; Kiser, W.S.; Straffon, R.A. The treatment of patients with interstitial cystitis, with special reference to intravesical DMSO. J. Urol. 1972, 107, 377-380. [CrossRef]

20. Grover, S.; Srivastava, A.; Lee, R.; Tewari, A.K.; Te, A.E. Role of inflammation in bladder function and interstitial cystitis. Adv. Urol. 2011, 3, 19-33. [CrossRef]

21. Shiga, K.I.; Hirano, K.; Nishimura, J.; Niiro, N.; Naito, S.; Kanaide, H. Dimethyl sulphoxide relaxes rabbit detrusor muscle by decreasing the Ca2+ sensitivity of the contractile apparatus. Br. J. Pharmacol. 2007, 151, 1014-1024. [CrossRef] [PubMed]

22. Petrou, S.P.; Parker, A.S.; Crook, J.E.; Rogers, A.; Metz-Kudashick, D.; Thiel, D.D. Botulinum a toxin/dimethyl sulfoxide bladder instillations for women with refractory idiopathic detrusor overactivity: A phase 1/2 study. Mayo Clin. Proc. 2009, 84, 702-706. [CrossRef] [PubMed]

23. Gurpinar, T.; Truong, L.D.; Wong, H.Y.; Griffith, D.P. Electromotive drug administration to the urinary bladder: An animal model and preliminary results. J. Urol. 1996, 156, 1496-1501. [CrossRef]

24. Slater, S.E.; Patel, P.; Viney, R.; Foster, M.; Porfiri, E.; James, N.D.; Montgomery, B.; Bryan, R.T. The effects and effectiveness of electromotive drug administration and chemohyperthermia for treating non-muscle invasive bladder cancer. Ann. R. Coll. Surg. Engl. 2014, 96, 415-419. [CrossRef]

25. Di Stasi, S.M.; Giannantoni, A.; Stephen, R.L.; Capelli, G.; Navarra, P.; Massoud, R.; Vespasiani, G. Intravesical electromotive mitomycin $\mathrm{C}$ versus passive transport mitomycin $\mathrm{C}$ for high risk superficial bladder cancer: A prospective randomized study. J. Urol. 2003, 170, 777-782. [CrossRef] 
26. Di Stasi, S.M.; Valenti, M.; Verri, C.; Liberati, E.; Giurioli, A.; Leprini, G.; Masedu, F.; Ricci, A.R.; Micali, F.; Vespasiani, G. Electromotive instillation of mitomycin immediately before transurethral resection for patients with primary urothelial non-muscle invasive bladder cancer: A randomised controlled trial. Lancet. Oncol. 2011, 12, 871-879. [CrossRef]

27. Di Stasi, S.M.; Giannantoni, A.; Massoud, R.; Dolci, S.; Navarra, P.; Vespasiani, G.; Stephen, R.L. Electromotive versus passive diffusion of mitomycin $\mathrm{C}$ into human bladder wall: Concentration-depth profiles studies. Cancer Res. 1999, 59, 4912-4918.

28. CADTH Rapid Response Reports. The Use of the Electromotive Drug Administration System in Patients with Overactive Bladder: A Review of the Clinical Effectiveness, Safety, and Cost-Effectiveness; Canadian Agency for Drugs and Technologies in Health: Ottawa, ON, Canada, 2014.

29. Kajbafzadeh, A.M.; Ahmadi, H.; Montaser-Kouhsari, L.; Sharifi-Rad, L.; Nejat, F.; Bazargan-Hejazi, S. Intravesical electromotive botulinum toxin type A administration-part II: Clinical application. Urology 2011, 77, 439-445. [CrossRef]

30. Ladi-Seyedian, S.S.; Sharifi-Rad, L.; Kajbafzadeh, A.M. Intravesical Electromotive Botulinum Toxin Type "A" Administration for Management of Urinary Incontinence Secondary to Neuropathic Detrusor Overactivity in Children: Long-term Follow-up. Urology 2018, 114, 167-174. [CrossRef]

31. Wang, H.J.; Cheng, J.H.; Chuang, Y.C. Potential applications of low-energy shock waves in functional urology. Int. J. Urol. Off. J. Jpn. Urol. Assoc. 2017, 24, 573-581. [CrossRef]

32. Chuang, Y.C.; Huang, T.L.; Tyagi, P.; Huang, C.C. Urodynamic and Immunohistochemical Evaluation of Intravesical Botulinum Toxin A Delivery Using Low Energy Shock Waves. J. Urol. 2016, 196, 599-608. [CrossRef] [PubMed]

33. Nageib, M.; El-Hefnawy, A.S.; Zahran, M.H.; El-Tabey, N.A.; Sheir, K.Z.; Shokeir, A.A. Delivery of intravesical botulinum toxin A using low-energy shockwaves in the treatment of overactive bladder: A preliminary clinical study. Arab J. Urol. 2019, 17, 216-220. [CrossRef] [PubMed]

34. Hung, S.-Y.; Chancellor, D.D.; Chancellor, M.B.; Chuang, Y.-C. Role of liposome in treatment of overactive bladder and interstitial cystitis. Urol. Sci. 2015, 26, 3-6. [CrossRef]

35. Chuang, Y.C.; Lee, W.C.; Lee, W.C.; Chiang, P.H. Intravesical liposome versus oral pentosan polysulfate for interstitial cystitis/painful bladder syndrome. J. Urol. 2009, 182, 1393-1400. [CrossRef] [PubMed]

36. Chuang, Y.C.; Tyagi, P.; Huang, C.C.; Yoshimura, N.; Wu, M.; Kaufman, J.; Chancellor, M.B. Urodynamic and immunohistochemical evaluation of intravesical botulinum toxin A delivery using liposomes. J. Urol. 2009, 182, 786-792. [CrossRef] [PubMed]

37. Kuo, H.C.; Liu, H.T.; Chuang, Y.C.; Birder, L.A.; Chancellor, M.B. Pilot study of liposome-encapsulated onabotulinumtoxina for patients with overactive bladder: A single-center study. Eur. Urol. 2014, 65, 1117-1124. [CrossRef]

38. Chuang, Y.C.; Kaufmann, J.H.; Chancellor, D.D.; Chancellor, M.B.; Kuo, H.C. Bladder instillation of liposome encapsulated onabotulinumtoxina improves overactive bladder symptoms: A prospective, multicenter, double-blind, randomized trial. J. Urol. 2014, 192, 1743-1749. [CrossRef]

39. Chuang, Y.C.; Kuo, H.C. A Prospective, Multicenter, Double-Blind, Randomized Trial of Bladder Instillation of Liposome Formulation OnabotulinumtoxinA for Interstitial Cystitis/Bladder Pain Syndrome. J. Urol. 2017, 198, 376-382. [CrossRef]

40. Lee, W.C.; Su, C.H.; Tain, Y.L.; Tsai, C.N.; Yu, C.C.; Chuang, Y.C. Potential Orphan Drug Therapy of Intravesical Liposomal Onabotulinumtoxin-A for Ketamine-Induced Cystitis by Mucosal Protection and Anti-inflammation in a Rat Model. Sci. Rep. 2018, 8, 5795. [CrossRef]

41. Jeong, B.; Bae, Y.H.; Kim, S.W. Drug release from biodegradable injectable thermosensitive hydrogel of PEG-PLGA-PEG triblock copolymers. J. Control. Release Off. J. Control. Release Soc. 2000, 63, 155-163. [CrossRef]

42. Tyagi, P.; Li, Z.; Chancellor, M.; De Groat, W.C.; Yoshimura, N.; Huang, L. Sustained intravesical drug delivery using thermosensitive hydrogel. Pharm. Res. 2004, 21, 832-837. [CrossRef] [PubMed]

43. Krhut, J.; Navratilova, M.; Sykora, R.; Jurakova, M.; Gartner, M.; Mika, D.; Pavliska, L.; Zvara, P. Intravesical instillation of onabotulinum toxin A embedded in inert hydrogel in the treatment of idiopathic overactive bladder: A double-blind randomized pilot study. Scand. J. Urol. 2016, 50, 200-205. [CrossRef] [PubMed] 
44. Rappaport, Y.H.; Zisman, A.; Jeshurun-Gutshtat, M.; Gerassi, T.; Hakim, G.; Vinshtok, Y.; Stav, K. Safety and Feasibility of Intravesical Instillation of Botulinum Toxin-A in Hydrogel-based Slow-release Delivery System in Patients With Interstitial Cystitis-Bladder Pain Syndrome: A Pilot Study. Urology 2018, 114, 60-65. [CrossRef] [PubMed]

45. El Shatoury, M.G.; DeYoung, L.; Turley, E.; Yazdani, A.; Dave, S. Early experimental results of using a novel delivery carrier, hyaluronan-phosphatidylethanolamine (HA-PE), which may allow simple bladder instillation of botulinum toxin A as effectively as direct detrusor muscle injection. J. Pediatric Urol. 2018, 14, 172.e171-172.e176. [CrossRef] [PubMed]

(C) 2020 by the authors. Licensee MDPI, Basel, Switzerland. This article is an open access article distributed under the terms and conditions of the Creative Commons Attribution (CC BY) license (http://creativecommons.org/licenses/by/4.0/). 